\title{
EVSItalia Database of Evergreen Mediterranean Forests
}

\author{
Emiliano Agrillo, Francesco Spada \& Simonetta Valfré
}

\begin{abstract}
A database of the Evergreen Mediterranean Forests of peninsular Italy is presented (EVSItalia Database of Evergreen Mediterranean Forests, GIVD ID EU-IT-014). The database stores 1,266 relevés from published certified phytosociological sources, belonging to the syntaxa of Quercion ilicis. Specifically, Quercus ilex forest of Viburno-Quercetum ilicis and the cork oak forest in the syntaxa of Viburno-Quercetum ilicis suberetosum (according to a central- Mediterranean classical interpretation). Q. suber stands are a variant of the $Q$. ilex forests, although the continued exploitation of cork and grazing activities in the cork forests, do not allow a precise analysis of the true spatial limits of the two biocoenoses. All the relevés are uploaded to TURBOVEG; a related ArcGIS Database stores information about localization: Operational Geographic Units (OGU), corresponding to the quadrates of the Italian floristic grid, precise GPS or toponym information as well as descriptive records of locations extracted from geographical information systems are stored. The data-set aims to support reviews based on large data-sets for the classification of Italian vegetation types, classification of communities and their parameterization over larger areas by geostatistical analysis, the exploration geographic changes in community distribution along topographical gradients and to test changes along geographical gradients. A different insight in the patterns of synonymy and reassessment among syntaxa on the basis of a geographical approach is expected.
\end{abstract}

Keywords: Italian vegetation database; TURBOVEG.

\section{GIVD Database ID: EU-IT-014 \\ EVSItalia Database Evergreen Mediterranean Forests}

Last update: 2012-07-25

Scope: The data-set aims to store information from published/certified phytosociological sources in order to support ongoing reviews based on larger data-sets for comparative classification of Italian vegetation types.

Status: completed and continuing Period: $1923-2009$

Database manager(s): Emiliano Agrillo (emiliano.agrillo@uniroma1.it)

Owner: [NA]

Web address: [NA]

Availability: according to a specific agreement

Online upload: no Online search: no

Database format(s): TURBOVEG, ArcGis database

Export format(s): TURBOVEG, ArcGis database

Publication: [NA]

Plot type(s): normal plots

Plot-size range: $20-500 \mathrm{~m}^{2}$

Non-overlapping plots: 1,366

Total plot observations: 1,366

Completeness: [NA]

Estimate of existing plots: [NA]

Valid taxa: [NA]

Countries: IT: $75.0 \%$

Forest: [NA] — Non-forest: [NA]

Guilds: all vascular plants: $100 \%$; bryophytes (terricolous or aquatic): $5 \%$

Environmental data: [NA]

Performance measure(s): [NA]

Geographic localisation: [NA]

Sampling periods: [NA]

Information as of 2012-07-12; further details and future updates available from http://www.givd.info/ID/EU-IT-014

Emiliano Agrillo* (emiliano.agrillo@uniroma1.it), Francesco Spada (francesco.spada@uniroma1.it), Simonetta Valfrè

(simonetta.valfre@uniroma1.it)

Department of Environmental Biology, Sapienza University of Roma, Rome, ITALY

*Corresponding author 